\title{
INTERNATIONAL ENVIRONMENT PROTECTION DURING ARMED CONFLICT CASE STUDY: ISRAEL-LEBANON CONFLICT
}

\author{
Arie Afriansyah ${ }^{*}$
}

\section{Abstrak}

During the last decade many armed conflicts were occurred between nations or states. From that situation initially people just have interests through human who been victim more than environment destructions that had been affected. Furthermore since those environment defects have influenced through human living then triggered awareness toward worst effect of the war. The author by this article does configure how by conflict between Israel and Lebanon (Hezbollah) have shaped bad affects not only to local but also regionally through the environment. Under that elaboration then will examine how to resolve the conflict under international law and also to ascertain state liability through environment destruction what was ensued

Keywords: international environmental law, armed conflict, environment protection, state responsibility

\section{Introduction}

In the last ten decades, many armed conflicts have occurred among peoples and states. The conflict might happen not only between two powers but also involved almost all states which are called the World Wars. These armed conflicts always considered as the last resort by states to solve national or international conflict. However, unfortunately in reality, war is more likely to happen than peaceful settlement because States with strong military power tend to prefer war which has bigger possibility to gain victory over other States. These poignant realities are not eventually undermined peaceful efforts such as negotiation, mediation, and other pacific settlements. These efforts are the principal means to manage conflicts in international law, nonetheless, some suggests that it also showed that the limitation of international law during the armed conflict. ${ }^{1}$

* Lecturer at International Law Department, Faculty of Law University of Indonesia. LL.B (Sarjana Hukum) from the University of Indonesia (2003) and Master of International Law (M.I.L.) from the University of Sydney (2006). 
Generally speaking, at the beginning, people were only concerned to human as the victim of war. They did not consider the environmental damaged as the effect of the war. However, as the growing concern in international community to the environmental damage which have great impact to human life, people are now more aware of the war effect to the environment. Some had argued that the environment was frequently both being the victim and a tool of armed conflict. ${ }^{2}$ Some had further argued that attacking the environment as a means of waging war was not a new concept. ${ }^{3}$ These arguments show that environment eventually play an important role during the warfare. Further, some would argued that military acts that cause extensive and severe harm to the environment also be counted as the grave breaches of the laws of armed conflict. ${ }^{4}$

Despite extensive researches on how to prevent damage, and many international instruments that aim to prevent environmental harm, ${ }^{5}$ armed conflicts which had happened until today are highly likely brought great environmental damages that raise international community's deep concern. The perpetrators of the war might argue that objects which they had been destroyed are important targets that outweighed the importance of environmental impact. However, this reason was not a reasonable justification to harm the environment while its impacts could jeopardise present generations or even future generations. ${ }^{6}$

${ }^{1}$ David Hunter, James Salzman and Durwood Zaelke, "International Environmental Law and Policy", $2^{\text {nd }}$ edition, (New York: Foundation Press, 2002), p. 1379.

2 Tara Weinstein, "Prosecuting Attacks that Destroy the Environment: Environmental Crimes or Humanitarian Atrocities?", Georgetown International Environmental Law Review, 17 (4) (2005), p. 698.

${ }^{3}$ Major Bernard K. Schafer, "The Relationship between the International Laws of Armed Conflict and Environmental Protection: The Need to Re-evaluate What Types of Conduct are Permissible during Hostilities", California Western International Law Journal, 19 (1988-1989), p. 288.

${ }^{4}$ Gregory Reichberg and Henrik Syse, "Protecting the Natural Environment in Wartime: Ethical Considerations from the Just War Tradition" Journal of Peace Research, 37 (4) (2000), p. 449.

${ }^{5}$ Loc. Cit., Weinstein.

6 Ved P. Nanda, "International Environmental Law \& Policy", (New York: Transnational Publishers Inc., 1995), 61. See Ben Boer, "The Globalisation of the Environmental Law: The Role of the United Nations", Melbourne University Law Review, 20 (1995), p. 109-111. 
There are many examples of war which have great impact to environment. These include the Persian Gulf War in 1990, the Kosovo conflict in 1999, and the conflict between Israel-Lebanon (Hezbollah) ${ }^{7}$. The latter conflict will be the focus of this essay.

In the 1990 Persian Gulf War, the environmental damage was happen when Iraqi military set fires to oil installations in Kuwait as retaliation acts to coalition of military forces. The oil spill had polluted Persian Gulf and affected the wildlife of the region and affected Kuwait's neighbours especially in the fresh water supply. ${ }^{8}$ To solve the damage, the total cost of reconstruction and rehabilitation was estimated up to two billion US dollars. ${ }^{9}$ In institutional aspect, the Security Council created the United Nations Compensation Commission (UNCC) to assess damages and to receive compensation from Iraq. ${ }^{10}$

Meanwhile, the environmental damage as the effect of the 1999 Kosovo conflict was triggered by NATO's military actions to some important assets such as industrial facilities, factories, oil refineries and fuel storage of the FRY (Federal Republic of Yugoslavia). Unfortunately, the bombardments of those facilities caused environmental problem where the Danube River was being polluted and affected downstream countries like Romania and Bulgaria. The pollution was caused by oil spills and toxic chemical dumping which threatened the existence of wildlife of the river. ${ }^{11}$

The last conflict example was the conflict between Israel and Lebanon (Hezbollah). In this conflict, Israeli military forces had set fires to Lebanon's infrastructures and one of it was Jiyyeh power station. This situation invites international community's deep concern because it produce huge oil spill into Mediterranean Sea which threatened the wildlife including Bluefin Tuna and Green Turtles and also affected their neighbouring states Cyprus,

${ }^{7}$ Hezbollah is a left wing faction in Lebanon that consistently against the Israeli presence in the Southern Lebanon.

8 Jessica E. Seacor, "Environmental Terrorism: Lessons from the Oil Fires of Kuwait", American University Journal of International Law, 10 (1994), p. 487.

${ }^{9}$ Major Walter G. Sharp, Sr., "The Effective Deterrence of Environmental Damage during Armed Conflict: A Case Analysis of the Persian Gulf War", Military Law Review, 137 (1992), p. 42.

${ }^{10}$ Mariano J. Aznar-Gomez, "Environmental Damages and the 1991 Gulf War: Some Yardstick Before the UNCC", Leiden Journal of International Law, 14 (2001), p. 303.

${ }^{11}$ Ida L. Bostian, "The Environmental Consequences of the Kosovo Conflict and the NATO Bombing of Serbia", Colorado Journal of International Environmental Law and Policy, 11 (2000), p. 230-234. 
Turkey, and even Greece. ${ }^{12}$ Meanwhile, Hezbollah troops had caused forest fire in Israel territory which likely to destroyed the existence wildlife and produced air pollution. ${ }^{13}$

Before discussing a detail description of the environmental problem from the Israel-Lebanon (Hezbollah) conflict, the essay will begins with brief description of international legal protections of the environment during the armed conflict as the basis of analysis in international law in general and international environmental law in particular. In the following, this essay will describe the Israel-Lebanon (Hezbollah) conflict as a case study that had a result of environmental damages. Having given all the facts, it then examines whether the conflict had conducted under international law and tries to seek out state's responsibility of environmental damages that have been produced by the conflict.

With Israel-Lebanon (Hezbollah) conflict as the most recent example, this essay tries to explain how armed conflict could severely affect the environment not only local but also regional area. Other point that need to be considered are in to what extent that military force in armed conflict justified destroying the environment. Present with so many international instrument regulating conduct of war, it concludes that to some extent these instruments are not effective to protect the environment from damage. In the case of Israel and Lebanon (Hezbollah) conflict, it can be argued that both parties are responsible for breaching international law on environment protection during armed conflict and therefore hold the main responsibility to all the damages.

\section{Environmental Protection and the Laws of War}

In present days, international community has agree to avoid as far as they can in using use of violence or military force in relations among states. This principle is embodied in Article 2 paragraph 4 of the UN Charter. Interestingly to note, the Charter also provides exception to this non-use of force which so called as an act of self defence in Article 51. Even though the principle of prohibition of the threat or the use of force is regarded as the central rules on the use of force, debates are still flourishing in international

${ }^{12}$ MSNBC News On-line (USA), "Israeli Attacks Spawn Environmental Disaster: Bombardment Unleashes Oil into Mediterranean Sea, Killing Fish, Turtles", 26 July 2006 $<$ http://www.msnbc.msn.com/id/14138687/>, accessed August 19, 2006.

13 MSNBC News On-line (USA), "Nature Falls Victim to Hezbollah Rocket Attacks", 26 July 2006, <http://www.msnbc.msn.com/id/14153579/>, accessed August 19, 2006. 
community itself whether this principle is not only treaty and customary law but it is also as jus cogens. ${ }^{14}$

As the armed conflict is considered to be inevitable in some events, international law had eventually given regulations to control the conduct during the war. Moreover, it already refers to the protection of environment in time of conflict. Edith Brown Weiss noted that the history had showed this practice. ${ }^{15}$ She gave examples of religion practice where the Old Testament outlaws a party in besieging a city from cutting down the fruit trees and the Islamic tradition prohibits conquerors tearing down crops and livestock.

It is important to note that the first international law in armed conflict in early $21^{\text {st }}$ century was 1907 Hague Conventions with its Fourth Convention in concerning the Laws and Customs of War on Land. Through this convention, it can be argue that environment protection was implicitly embodied in its annexed Regulations. ${ }^{16}$ In Article 22 of The Hague Regulations, it developed the underlying idea of restraint which stated that "the right of belligerents to adopt means of injuring the enemy is not unlimited." ${ }^{\text {17 }}$ Moreover, the Hague Regulations in Article 23(g) stated that it is prohibited "to destroy or seize the enemy's property, unless such destruction or seizure be imperatively demanded by the necessities of war."

In addition to that, in 1949, there was another protection provision in the Fourth Geneva Convention. ${ }^{19}$ It sets restrictions in the event of belligerent occupation to the discretion of the occupying power and states that "any destruction by the Occupying Power of real or personal property belonging individually or collectively to private persons, or to the State, or to other public authorities ... is prohibited, except where such destruction is rendered

${ }^{14}$ Christine Gray, "International Law and the Use of Force", $2^{\text {nd }}$ edition, (New York: Oxford University Press, 2004), p. 29.

${ }^{15}$ Edith Brown Weiss, Introductory Remarks on The International Responses to the Environmental Impacts of War Symposium, Georgetown International Environmental Law Review, 17(4) (2005): 568.

${ }^{16}$ Regulations Respecting the Laws and Customs of War on Land, annexed to Convention Respecting the Laws and Customs of War on Land, Oct. 18, 1907, 36 Stat. 2277 (1911), T.S. No. 539. [hereinafter Hague Regulations].

${ }^{17} \mathrm{Ibid}$, Art. 22.

${ }^{18}$ Ibid, Art. 23(g).

${ }^{19}$ Geneva Convention Relative to the Protection of Civilian Persons in Time of War, Aug. 12, 1949, 75 UNTS 287. 
absolutely necessary by military operations". ${ }^{20}$ Therefore, it can be concluded that The Hague Regulations and the Fourth Geneva Convention implicitly protect the environment by proscribing the futile destruction of property.

It is noteworthy that this implicit or indirect environment protection in international law makes its enforcement is likely to be considered weak. Gasser argues that international humanitarian law, like international law in general, has been sluggish to recognise that the natural environment also necessitates the protection of legal rules specifically for that purpose. He then says that the idea of "natural environment" does not emerge in an instrument of humanitarian law until $1977 .{ }^{21}$

In 1977, it is significant to say that there are two international instruments of which directly recognise the environment protection during armed conflict. The instruments are Protocol I of 1977 additional to the Geneva Conventions of $1949^{22}$ and the ENMOD Convention. ${ }^{23}$ International Committee of the Red Cross (ICRC) in its advisory service on international humanitarian law said that the provisions of Protocol I form an important accompaniment to those of the ENMOD Convention, as they directly disallow harm to the environment during armed conflict. ${ }^{24}$

It appears that there are two provisions in Protocol I which deal directly to environment protection. Firstly, Article 35(3) prohibits the use of force which might lead "to cause widespread, long-term and severe damage to the natural environment". Secondly, Article 55 aims to protect the people, whose health and survival in the time of armed conflict could be harmed by

${ }^{20}$ Ibid., Art. 53.

${ }^{21}$ Hans-Peter Gasser, "For Better Protection of the Natural Environmental in Armed Conflict: A Proposal for Action", American Journal of International Law, 89(3) (1995), p. 638.

${ }^{22}$ Protocol Additional to the Geneva Conventions of 12 August 1949, and Relating to the Protection of Victims of International Armed Conflicts, Dec. 12, 1977, 1125 UNTS 3, reprinted in 16 ILM 1391, (1977) [hereinafter Protocol I].

23 Convention on the Prohibition of Military and Other Hostile Use of Environmental Modification Techniques, opened for signature May 18, 1977, 1108 UNTS 151 , reprinted in $16 \mathrm{ILM}, 88$ (1977) [hereinafter the ENMOD Convention].

${ }^{24}$ ICRC, "Advisory Service on International Humanitarian Law", available at $<$ http://www.icrc.org/Web/Eng/siteeng0.nsf/htmlall/57JR8J/\$FILE/1976_ENMOD.pdf?Open Element\#search=\%22\%221976\%20Convention $\% 20$ on $\% 20$ the $\% 20$ Prohibition $\% 20$ of $\% 20$ Milit ary\%22\%22>, accessed August 19, 2006. 
damage to the environment. It also bans assaults on the natural environment by way of retaliations.

Besides those two provisions, there are other provisions of Protocol I which relates incidentally on the protection of the environment. Article 36 requires the states party to verify whether the use of a new weapon which will be developed, tested or purchased would be compatible with obligations under international law, among which the protection of the environment. Article 54 and 56 protect the civilian by prohibiting attacks on works and installations containing dangerous forces such as dams, dikes and nuclear power stations which might threaten its sustenance.

The ENMOD Convention is particularly intended to prevent use of the environment as a means of warfare, by barring the intentional manipulation of natural processes that could produce phenomena as natural catastrophe. The convention obliges States party "not to engage in military or any other hostile use of environmental modification techniques having widespread, long-lasting or severe effects as the means of destruction, damage or injury to any other State Party". ${ }^{25}$ It also further requires States parties not to "assist, encourage or induce" any state, group of States or international organisation to involve in such activities. ${ }^{26}$ The convention explains the notion of environmental modification techniques as intentional means to change "through the deliberate manipulation of natural processes, the dynamics, composition or structure of the Earth". ${ }^{27}$

In response to the environmental consequences of the armed conflict in the gulf area, the Governing Council of the UNEP recommended that actions to be taken to prohibit weapons that "cause particularly serious effects on the environment. ${ }^{, 28}$ This recommendation was brought into the UN Conference on Environment and Development which held in Rio de Janeiro on June 1992. The recommendation was included in its Rio Declaration on Environment and Development in the Principle 24 which stated that "Warfare is inherently destructive of sustainable development. States shall therefore respect international law providing protection for the environment

\footnotetext{
${ }^{25}$ Loc. Cit., ENMOD Convention, Art. I (1).

${ }^{26}$ Ibid., Art. I (2).

${ }^{27}$ Ibid., Art. II.

${ }^{28}$ UNEP, Governing Council, $16^{\text {th }}$ Sess., Resolution $16 / 11$ on Military Conflicts and
} the Environment (May 31, 1991), reprinted in UN Doc. A/46/25, (1991). 
in times of armed conflict and cooperate in its further development, as necessary. $" 29$

In the same year, United Nations General Assembly (UNGA), under the title "Protection of the Environment in Times of Armed Conflict", adopted Resolution $47 / 37,{ }^{30}$ which refers comprehensively to the international law on the protection of the environment. It also calls to states to become party to the important international conventions and urges them to take all measures to make sure fulfilment with those obligations, for example by including them into military manuals.

The resolution also invited the ICRC to continue its work in this field and to report its conclusions to the UNGA. From this invitation, ICRC had submitted its proposed guidelines to $\mathrm{UNGA}^{31}$ and it was unofficially approved as an agreed proposal of its Sixth Committee, included the subsequent paragraph in its resolution entitled "UN Decade of International Law": ${ }^{32}$

The General Assembly

11. Invites all States to disseminate widely the revised guidelines for military manuals and instructions on the protections of the environment in times of armed conflict received from the International Committee of the Red Cross and to give due consideration to the possibility of incorporating them into their military manuals and other instructions addressed to their military personnel.

The Guidelines ${ }^{33}$ highlighted and reaffirmed specific provisions of international law which related to the protection of the environment during

29 Rio Declaration on Environment and Development, UN Doc. A/CONF.151/ 5/Rev.1, reprinted in 31 ILM 874, (1992).

${ }^{30}$ GA Res. 47/37, (Nov. 25, 1992).

31 UN Doc. A/49/323 (1994), in particular its Annex: Guidelines for Military Manuals and Instructions on the Protection of the Environment in Times of Armed Conflict.

${ }^{32}$ GA Res. 49/50, (Dec. 9, 1994). 
armed conflict. It also stressed that international environmental agreements and relevant rules of customary law may continue to applicable in times of armed conflict to the extent that they are not inconsistent with the applicable law of armed conflict. ${ }^{34}$

Another important international instrument in environment protection was the International Court of Justice's (ICJ) advisory opinion concerning the legality of the threat or use of nuclear weapon in $1996 .{ }^{35}$ Even though the opinion was substantially about the use of nuclear weapon, it covers specific paragraphs which recognised the importance of environment protection in States' practice. In its opinion, it scrupulously makes reference to all relevant international instruments not only direct provisions but also implicit or indirect provisions to environment protection such as Additional Protocol I of 1977 to the Geneva Conventions of 1949 and the Convention on the Prohibition of Military or Any Other Hostile Use of Environmental Modification Techniques of 18 May 1977.

The Court firstly recognises the existence of the general obligation of States to make sure that activities within their jurisdiction and control respect the environment of other States or of areas beyond national control as the main principle of international law relating to the environment. ${ }^{36}$ It can be maintained that this obligation is considered as international customary law where it takes from Principle 21 of the Stockholm Declaration of 1972 and Principle 2 of the Rio Declaration of 1992. The Court also finds that the obligations stemming from international instruments were intended to be obligations of entirety control during military conflict. The Court determines that "States must take environmental considerations into account when assessing what is necessary and proportionate in the pursuit of legitimate military objectives. ${ }^{\text {,37 }}$

Finally, in relation to environment protection, the Court finds that while the existing international law relating to the protection and safeguarding of the environment does not specifically prohibit the use of

33 Guidelines for Military Manuals and Instructions on the Protection of the Environment in Times of Armed Conflict. UN Doc. A/49/323, Aug. 19, 1994.

34 Adam Roberts, "The Law of War and Environmental Damage", in The Environmental Consequences of War: Legal, Economic, and Scientific Perspectives, eds. Jay E. Austin and Carl E. Bruch, (Cambridge: Cambridge University Press, 2000), p. 72.

${ }^{35}$ Legality of the Threat or Use of Nuclear Weapons (Advisory Opinion), [1996] ICJ Rep. 95 [Opinion].

${ }^{36}$ Ibid., paragraph 29.

${ }^{37}$ Ibid., paragraph 30 . 
nuclear weapons, it indicates important environmental factors that are properly to be taken into account in the context of the implementation of the principles and rules of the law applicable in armed conflict." ${ }^{38}$ It can be argued that, therefore, ICJ had strengthened the international instruments on environment protection during the armed conflict.

In the recent development, it is interestingly to note that the "war crime to the environment" was categorised as international criminal law which included in the International Criminal Court. The Rome Statute of 1998 stated that the Court has jurisdiction in respect of war crimes that consist in "intentionally launching an attack in the knowledge that such attack will cause incidental ... widespread, long-term and severe damage to the natural environment which would be clearly excessive in relation to the concrete and direct overall military advantage anticipated". ${ }^{39}$ From this point, it opens the possibility in the future to bring individual before the court who commits a war crime that result a severe damage to the environment. ${ }^{40}$

\section{Environmental Damage from Jiyyeh's Oil Spill and Naftali Forest Fire}

In early July 2006, Hezbollah's armed force, in small raid in Lebanon's border with Israel, was kidnapping two Israeli soldiers as the respond to Israel occupation in southern Lebanon. ${ }^{41}$ Israel warned Hezbollah to surrender its soldiers but Hezbollah refused it. Because of that, Israel started uses its military power and claimed it as an act of self defence to attack Lebanon with the mission to bring back its soldiers and to disarm Hezbollah, government's main party.

Israel sends their missiles to Hezbollah's main assets and infrastructure in Lebanon territory such as Beirut and southern part of Lebanon. One of its targets was power supply to the government which was petrol station. This mission was the starting point to which the environmental damage was happened. A/CONF.183/9.

${ }^{38}$ Ibid., paragraph 33.

${ }^{39}$ Article $8(2)[\mathrm{b}, \mathrm{iv}]$ the Rome Statute of International Criminal Court, U.N. Doc.

${ }^{40}$ Loc. Cit. Weinstein.

41 Joshua Frank, "Kidnapped in Israel or Captured in Lebanon? Official Justification for Israel's Invasion on Thin Ice", July 22, 2006, <http://www.antiwar.com/frank/>, accessed August 25, 2006. 
Between 13 and 15 July 2006, Israel attacked the Jiyyeh's power station which located $30 \mathrm{~km}$ south of Beirut. Approximately 10.000 tonnes of heavy oil were spilled into Mediterranean Sea. Some reports suggest that the actual number could 35.000 tonnes of heavy oil. While local environmental groups claimed that the oil slick as an "environmental disaster" which could be compared with the 1989 Exxon Valdez tanker incident in Alaska. Furthermore, UNEP (United Nations for Environmental Programme) stated that this incident was a significant threat to some Mediterranean wildlife. ${ }^{42}$

From this incident, an environmentalist group, Green Line, said that some of the oil has reached on the sea floor, threatening areas where tuna is spawning. They also said that oil on beaches will prevent baby turtles, which are endangered species, from reaching the sea after they hatch. The burning oil also sends waves of black smoke toward the city and its suburbs so that caused air pollution. ${ }^{43}$ The oil spills not only damaged one third of Lebanon's beaches ${ }^{44}$ but also reached part of Syrian beach. Some suggest that if the oil spill is not managed promptly, it will affect also to Cyprus, Turkey and even Greece. $^{45}$

Besides the oil spill, environmental impact during the conflict was also experienced by Israel when Hezbollah's rockets hit forests and fields across northern Israel. According to Michael Weinberger, the forest supervisor for the Jewish National Fund, the top administrator of Israel's forests, the rocket fire has destroyed 16.500 acres of forests and grazing fields. ${ }^{46}$ These fires have threatened the ecosystem of the forest.

The Mount Naftali Forest was one of the areas which the fire occurs badly. The fire was wiping out some 750 acres and trapping gazelles, coyotes, jackals, rabbits and snakes. According to Omri Bonneh, the director

${ }^{42}$ BBC News On-line (UK), "Environmental 'Crisis' in Lebanon", 22 July 2006 Lttp://news.bbc.co.uk/2/hi/science/nature/5233358.stm>, accessed August 19, 2006.

${ }^{43}$ IRIN News On-line (UN), "An Environmental Disaster Looms", 22 July 2006 Lhtip: $/$ www.irinnews.org/report.asp?ReportID $=54881 \&$ SelectRegion=Middle_East\&Select Country=LEBANON>, accessed August 19, 2006.

${ }^{44}$ Planet Ark News On-line, "Oil Plant Leak Damages Third of Lebanon's CoastIMO", 22 July $2006<$ http://www.planetark.com/dailynewsstory.cfm/newsid/37489/newsDate B-Aug-2006/story.htm>, accessed August 19, 2006.

${ }^{45}$ Loc. Cit., MSNBC news on-line n. 12.

${ }^{46}$ Loc. Cit., MSNBC news on-line n.13. 
of the Jewish National Fund's northern region, forests will need 50 to 60 years to rehabilitate to what they were before fighting started. ${ }^{47}$

From the facts above, it is clearly that the conflict has brought severe damage to the environment. These damages were not only affected in local area but also widely regional area of the Middle East. It is significant to note that both parties to the conflict are significantly contributing and responsible to the damages because of their military power.

\section{Legal Consequences of the Conflict}

In discussing legal consequences from this conflict especially to the impact of the environment, there are two broad analyses in which recognised in international law concerning the laws of war. These broad analyses are determination of the legality use of force by the conflicting parties and justification factors i.e. necessity and proportionality. It can be argued that these discussion lead to the conclusion of which whether there is breach of international law especially to legal protection to the environment and whether the two conflicting States could be placed as the responsible parties of the environmental damages.

\section{Legality Use of Force}

Israel in its military campaign against Hezbollah was using "self-defence" reason to justify its action to the international community. ${ }^{48}$ Israel said that they did not have any choice left since all amicable efforts had been failed in order to bring their soldiers back and make peace with Lebanese government. ${ }^{49}$ Israel claimed that Hezbollah's raid in their border to Israeli military convoy and kidnapping its soldiers had triggered "armed attack" as the requirement to use military force in the reason of selfdefence. ${ }^{50}$ Therefore, Lebanon was responsible as a State which is

${ }^{47}$ Ibid.

${ }^{48}$ Michael Kelly, "Israel v. Hezbollah: Article 51, Self-Defence and Pre-emptive Strikes", Jurist Legal News \& Research (USA), 22 July 2006 <http:/jurist.law.pitt.edu/ forumy/2006/07/israel-v-hezbollah-article-51-self.php>, accessed August 23, 2006.

49 Wikipedia, "Israel-Lebanon Conflict", (2006) <http://en.wikipedia.org/wiki/ 2006_Israel-Lebanon_cōnflict>, accessed September 11, 2006. 
considered endorsing or tolerating Hezbollah's action. On the other side, Hezbollah had claimed that its action was a respond of Israel's continuing occupation in Southern Lebanon. ${ }^{51}$ In using its military power to Israel, Hezbollah claims that it is a legitimate act of self-defence since there are real armed attacks from Israel.

It is clear that both Israel and Hezbollah justify their action based on self-defence reason under Article 51 UN Charter. Article 51 recognises that the inherent right of individual or collective self-defence if an armed attack occurs against a Member of the United Nations. It is clear that action of self-defence is justified if an "armed attack" occurs. The ICJ, in its judgement in the Nicaragua case, determined that "armed attack" is including "action by regular armed forces across an international border and the sending by/on behalf of a state of armed bands, irregulars, mercenaries which carry out acts of such gravity as to amount to an actual armed attack by regular forces - or its substantial involvement therein". ${ }^{52}$ It is obvious to note from the word "occurs" that the armed attack begins not until a state's territory is affected.

It can be argued that Israel's justification of its action was flawed under Article 51. Hezbollah's military raid, of which claimed by Israeli government as an armed attack, was took place within the Lebanon's territory and outside Israel's territory where there is no significant implication. It also clear that there was no sending of armed bands by/on behalf of neither Hezbollah nor Lebanese government to Israel. In the other side, Hezbollah, in representing the government, had a clear justification of selfdefence when Israeli missiles were launched into Lebanese territory.

${ }^{50}$ New America Media, News Digest (USA), "Muslim and Arab Media Question Justification for Israeli Attacks", 20 July 2006, <http://news.newamericamedia.org/ news/view_article.html?article_id=34c469205888f8a949486a3b2f166964\&this_category_id= \&this_alt_category_id=402>, accessed September 11, 2006.

${ }^{51}$ Op. Cit., Wikipedia.

${ }^{52}$ Decision of the ICJ in Case Concerning Military and Paramilitary Acts in and Against Nicaragua, (Nicaragua v USA), 1986 ICJ Reports 14, par. 195. 


\section{Justification Factors: Necessity and Proportionality}

During the armed conflict, the conflicting parties are required to take into account of their actions based on necessity and proportionality assessments. This statement was considered as international customary law and reaffirmed by the ICJ in its judgement and advisory opinion. ${ }^{53}$ These are also applied not only to actions which will influence human but also to the environment. Given the main protection rules in the Protocol I to the Geneva Conventions of 1949 and the ENMOD convention, States are obliged not to use its military force which might lead to cause widespread, long-term and/or severe damage to the environment.

From the facts above, it can be argued that both Israel and Lebanon (Hezbollah) violate international law in protecting the environment during their military conflict. This was because Israel and Hezbollah intentionally attack power station and forest respectively in which both of them caused a cause widespread, long-term and/or severe damage to the environment. Therefore, Israel and Lebanon have violated the protection rules in Protocol I and the ENMOD convention.

It can be equally argued that Israel also failed to justify it actions in terms of necessity and proportionality. In the matter of necessity, even if there was an armed attack, Israel did not exhaustively seek another alternative means to repel the attack. It also seems that Israeli's military actions were premeditated because its actions begun after several days of the kidnapping.

In the matter of proportionality, Israel had shown even worse of its actions. Israel attacked most of Lebanon's infrastructures such as highways, bridges, buildings and fuel power stations. ${ }^{54}$ The latter was the one which had a severe impact to the marine environment and raised international concern over the impact. Israel claimed that this object was a legitimate target because it was supplying the fuel for Hezbollah's army. However, it is obvious to note that this attack had very little relation to Hezbollah but had huge impact to the environment because the oil spread along the coast and damaging the biodiversity of the

${ }^{53}$ Ibid., par. 176 and Loc. Cit., opinion, par. 41.

${ }^{54}$ Loc. Cit., Wikipedia. 
marine life. Moreover, the impact was not only within the Lebanon's territory but also affected its neighbouring countries such as Syria, Cyprus, Turkey and even Greece. ${ }^{55}$

It is understandable that Hezbollah had a justified basis to use its military force in order to repel Israel's armed attack over it territory. However, it is premature to maintain that Lebanon or Hezbollah also had a justification to its action which intentionally attacks Israel northern forests. Because of its attacks, wide-spread forest fires were occurring that destroying almost all the ecosystem of the forest and also spreading smoke onto regional area as a polluting substance in the air. ${ }^{56}$

It is clear that Israel and Lebanon cannot justify their action based on proportionality assessment in which result to a widespread, long-term and/or severe damage to the environment. It is also important to note that both States had violated the provisions about necessity and proportionality criteria in some international rules such as Article 23(g) of the Hague Regulations, Article 53 of the Fourth Geneva Convention, and Article 54 and 56 of the Protocol I.

If both Israel and Hezbollah were proved violating international law in protecting the environment during the armed conflict, it can be argued that in the future there is a possibility to bring both leaders before the ICC as war criminals to the environment. This is based on the ICC's jurisdiction over the "war crime to the environment" which is stated in Article $8(2)[b, i v]$ of its Statute. However, it can be also argued that it is highly likely in the near time of the future that this can happens since "war crime to the environment" is not as strong recognises as other international crime such as crimes against humanity and genocide.

In determining the liability of the crimes, there are so many difficulties for the international community to agree on certain criteria to classify it. ${ }^{57}$ The military necessity criterion is one of the hardest issues to make consensus. Some had been argued that military necessity has been subjectively defined by the commanders in wartime and has prevailed over inconsistent

${ }^{55}$ Loc. Cit., MSNBC News On-line, n.11.

${ }^{56}$ Ibid.

57 Robert Jarrett, "The Environment: Collateral Victim and Tool of War", Ilioscience, 53(9) (2003), p. 881. 
norms of customary international law associated with the legal duty to restrict methods and means of combat by reference to the capacity to distinguish military and non-military targets. ${ }^{58}$ Schmitt further argues that there are four categories of difficulties in implementing norms constraining environmental damage during armed conflict. These are prescriptive and definitional vagueness, disharmonious valuation paradigms, normative lacunae and goal disagreement. ${ }^{59}$ It is equally important to note that international relations theory may also be able to explain the non effectiveness of international environmental law implementation. ${ }^{60}$

As to all the "environmental targets" in Israel-Lebanon conflict, both parties claimed that all the targets were a legitimate military targets because they were have vital roles to the existence of both military powers. These claims were responded by the international community into two opposing view, pro and contra. However, as it showed by the real environmental damages, both claims cannot be justified in the basis of legitimate military target because it eventually do not have any real connection to both parties' military power other than only worse casualties.

Finally, it can be argued that, if no individual can be taken before the ICC, based on the principle of State Responsibility, both Israel and Lebanon are liable for paying compensations in order to redress all the environmental damages as the result of the conflict. This obligation emerges from Article 3 of Hague Convention $\mathrm{IV}^{61}$ and Article 91 of Additional Protocol $\mathrm{I}^{62}$.

58 Richard Falk, "The Environmental Law of War: An Introduction", in Environmental Protection and the Law of War: A"Fifth Geneva" Convention on the Environment in Time of Armed Conflict?, ed. Glen Plant, (New York: Belhaven Press, 1992), p. 80 and Michael N. Schmitt, "Green War: An Assessment of the Environmental Law of International Armed Conflict", Yale Journal of International Law, 22 (1) (1997), p. 54.

${ }^{59}$ Michael N. Schmitt, "War and the Environment: Fault Lines in the Prescriptive Landscape" in The Environmental Consequences of War: Legal, Economic, and Scientific Perspectives, eds. Jay E. Austin and Carl E. Bruch, (Cambridge: Cambridge University Press, 2000), p. 104.

${ }^{60}$ Tim Stephen, "The Role of International Courts and Tribunals in International Environmental Law", (D Phil Thesis, University of Sydney, 2005), p. 60.

${ }^{61}$ Article 3 Hague Convention IV stated that: 
Compensation is a mean of peaceful settlement which had been practiced by States for over a century. ${ }^{63}$ One of the clear example of this application was in the aftermath of the 1991 Gulf War where the UNCC became the independent body to receive and manage for claims as the result of the conflict. ${ }^{64}$

\section{Conclusion}

It is important to note that, because of armed conflict experiences, the international community has tried to protect the environment through conventional and customary international laws. However, until these days, if an armed conflict occurs, the environment continues to suffer and no individual has been charged with an environmental crime. There are many reasons for this condition such as ambiguity in the elements of the acts which constitute a war crime to the environment because of political sensitivities such as victor's justice and global social value system that allows environmental crimes to be overshadowed by humanitarian atrocities. ${ }^{65}$

It is clear that armed conflicts cause destruction on different kinds of victims, but unfortunately when the victim is the environment, perpetrators walk off without punishment. However, it is important to argue that legal consequences for those who cause environmental damage should be attached to deter the acts and remedy damage in maximum efforts. ${ }^{66}$ Then, it is

"A belligerent party which violates the provisions of the said Regulations shall, if the case demands, be liable to pay compensation. It shall be responsible for acts committed by members of its armed forces."

${ }^{62}$ Article 91 Additional Protocol I stated that:

"A party to the conflict which violates the provisions of the Conventions or of this Protocol shall, if the case demands, be liable to pay compensation. It shall be responsible for all acts committed by persons forming parts of its armed forces."

63 Adam Roberts, "Implementation of the Laws of War in Late $20^{\text {th }}$-Century Conflicts", Security Dialogue 29 (2) (1998), p. 144.

${ }^{64}$ Christopher D. Stone, "The Environment in Wartime: An Overview", in The Environmental Consequences of War: Legal, Economic, and Scientific Perspectives, eds. Jay E. Austin and Carl E. Bruch, (Cambridge: Cambridge University Press, 2000), p. 27-30.

${ }^{65}$ Loc. Cit., Weinstein, p. 721. 
significant to say that the State's responsibility is incur under international law if the armed forces of the State cause damage to the environment of other States by violating the laws of armed conflict. ${ }^{67}$

${ }^{66}$ Alexandre Kiss \& Dinah Shelton, International Environmental Law (London: Graham and Trotman, 1991), p. 347.

67 Christopher Greenwood, "State Responsibility and Civil Liability for Environmental Damage Caused by Military Operations" in Protection of the Environment During Armed Conflict, eds. Richard J. Grunawalt, John E. King and Ronald S. McClain, volume 69, (Newport RI: Naval War College, 1996), p. 412. 


\section{Bibliography}

\section{Books}

Falk, Richard. "The Environmental Law of War: An Introduction", in Environmental Protection and the Law of War: A "Fifth Geneva" Convention on the Environment in Time of Armed Conflict?, Glen Plant (ed), 78-89, London: Belhaven Press, 1992.

Gray, Christine. International Law and the Use of Force, $2^{\text {nd }}$ edition. New York: Oxford University Press, 2004.

Greenwood, Christopher. "State Responsibility and Civil Liability for Environmental Damage Caused by Military Operations" in Protection of the Environment During Armed Conflict, volume 69, Richard J. Grunawalt, John E. King and Ronald S. McClain (eds), 397-412. Naval War College, Newport, Rhode Island, 1996.

Hunter, David, James Salzman and Durwood Zaelke. International Environmental Law and Policy, $2^{\text {nd }}$ ed, New York: Foundation Press, 2002.

Kiss, Alexandre \& Dinah Shelton. International Environmental Law, London: Graham and Trotman, 1991.

Nanda, Ved P. International Environmental Law \& Policy, New York: Transnational Publisher Inc., 1995.

Roberts, Adam. "The Law of War and Environmental Damage" in The Environmental Consequences of War: Legal, Economic, and Scientific Perspectives, Jay E. Austin and Carl E. Bruch (eds), 47-86. Cambridge: Cambridge University Press, 2000.

Schmitt, Michael N. "War and the Environment: Fault Lines in the Prescriptive Landscape" in The Environmental Consequences of War: Legal, Economic, and Scientific Perspectives, Jay E. Austin and Carl E. Bruch (eds), 87-136. Cambridge: Cambridge University Press, 2000.

Stone, Christopher D. "The Environment in Wartime: An Overview", in The Environmental Consequences of War: Legal, Economic, and Scientific Perspectives, Jay E. Austin and Carl E. Bruch (eds), 16-38. Cambridge: Cambridge University Press, 2000. 


\section{Journal Articles}

Aznar-Gomez, Mariano J. "Environmental Damages and the 1991 Gulf War: Some Yardstick Before the UNCC", Leiden Journal of International Law, 14(2) (2001): 301-334.

Boer, Ben, "The Globalisation of the Environmental Law: The Role of the United Nations", Melbourne University Law Review, 20(1) (1995): 101-125.

Bostian, Ida L., "The Environmental Consequences of the Kosovo Conflict and the NATO Bombing of Serbia", Colorado Journal of International Environmental Law and Policy, 11 (2000): 230-240.

Gasser, Hans-Peter, "For Better Protection of the Natural Environmental in Armed Conflict: A Proposal for Action", American Journal of International Law, 89(3) (1995): 637-644.

Jarrett, Robert, "The Environment: Collateral Victim and Tool of War", Bioscience, 53(9) (2003): 880-883.

Reichberg, Gregory \& Henrik Syse, "Protecting the Natural Environment in Wartime: Ethical Considerations from the Just War Tradition", Journal of Peace Research, 37(4) (2000): 449-468.

Roberts, Adam, "Implementation of the Laws of War in Late $20^{\text {th }}$-Century Conflicts", Security Dialogue, 29(2) (1998): 137-150.

Seacor, Jessica E., "Environmental Terrorism: Lessons from the Oil Fires of Kuwait", American University Journal of International Law \& Policy, 10(1) (1994): 481-523.

Schafer, Major Bernard K., "The Relationship between the International Laws of Armed Conflict and Environmental Protection: The Need to Re-evaluate What Types of Conduct are Permissible during Hostilities", California Western International Law Journal, 19 (19881989) 287-325.

Schmitt, Michael N., "Green War: An Assessment of the Environmental Law of International Armed Conflict", Yale Journal of International Law, 22 (1) (1997): 1-109.

Sharp, Major Walter G., Sr., "The Effective Deterrence of Environmental Damage during Armed Conflict: A Case Analysis of the Persian Gulf War" Military Law Review, 137 (1992): 1-66. 
Weinstein, Tara, "Prosecuting Attacks that Destroy the Environment: Environmental Crimes or Humanitarian Atrocities?" Georgetown International Environmental Law Review, 17(4) (2005): 697-722.

Weiss, Edith Brown, Introductory Remarks on The International Responses to the Environmental Impacts of War Symposium Georgetown International Environmental Law Review, 17(4) (2005): 567-570.

\section{International Instruments}

Convention on the Prohibition of Military and Other Hostile Use of Environmental Modification Techniques, opened for signature, May 18, 1977, 1108 UNTS 151, reprinted in 16 ILM 88 (1977).

Decision of the ICJ in Case Concerning Military and Paramilitary Acts in and Against Nicaragua (Nicaragua v USA), 1986 ICJ Reports 14.

GA Res. 47/37 (Nov. 25, 1992).

GA Res. 49/50 (Dec. 9, 1994).

Geneva Convention Relative to the Protection of Civilian Persons in Time of War, Aug. 12, 1949, 75 UNTS 287.

Guidelines for Military Manuals and Instructions on the Protection of the Environment in Times of Armed Conflict. UN Doc. A/49/323, Aug. 19, 1994.

Legality of the Threat or Use of Nuclear Weapons (Advisory Opinion) [1996] ICJ Rep 95.

Protocol Additional to the Geneva Conventions of 12 August 1949, and Relating to the Protection of Victims of International Armed Conflicts, Dec. 12, 1977, 1125 UNTS 3, reprinted in 16 ILM 1391 (1977).

The Rome Statute of International Criminal Court, U.N. Doc. A/CONF.183/9.

Regulations Respecting the Laws and Customs of War on Land, annexed to Convention Respecting the Laws and Customs of War on Land, Oct. 18, 1907, 36 Stat. 2277 (1911), T.S. No. 539.

Rio Declaration on Environment and Development, UN Doc. A/CONF.151/5/Rev.1, reprinted in 31 ILM 874 (1992). 
UNEP, Governing Council, $16^{\text {th }}$ Sess., Resolution $16 / 11$ on Military Conflicts and the Environment (May 31, 1991), reprinted in UN Doc. A/46/25 (1991).

UN Doc. A/49/323 (1994), in particular its Annex: Guidelines for Military Manuals and Instructions on the Protection of the Environment in Times of Armed Conflict.

\section{Thesis/Dissertation}

Stephen, Tim, "The Role of International Courts and Tribunals in International Environmental Law", D. Phil Thesis, University of Sydney, 2005.

\section{Internet}

$B B C$ News On-line (UK), “Environmental 'Crisis' in Lebanon”, July 22, 2006, <http://news.bbc.co.uk/2/hi/science/nature/5233358.stm>, accessed August 19, 2006.

Frank, Joshua, "Kidnapped in Israel or Captured in Lebanon? Official Justification for Israel's Invasion on Thin Ice", July 22, 2006, $<\mathrm{http}$ ://www.antiwar.com/frank/>, accessed August 25, 2006.

ICRC, "Advisory Service on International Humanitarian Law", $<$ http://www.icrc.org/ Web/Eng/siteeng0.nsf/htmlall/57JR8J/\$FILE/ 1976_ENMOD.pdf?OpenElement\#search $=\% 22 \% 221976 \% 20$ Conventi on $\% 20$ on $\% 20$ the $\% 20$ Prohibition $\% 20$ of $\% 20$ Military $\% 22 \% 22>$, accessed August 19, 2006.

IRIN News On-line (UN), "An Environmental Disaster Looms", July 22, 2006, <http://www.irinnews.org/report.asp?ReportID=54881\&Select Region $=$ Middle_East\&SelectCountry $=$ LEBANON $>, \quad$ accessed August 19, 2006.

Kelly, Michael, Israel v. Hezbollah: Article 51, "Self-Defence and Preemptive Strikes", Jurist Legal News \& Research (USA), July 22, 2006, $<$ http://jurist.law. pitt.edu/forumy/2006/07/israel-v-hezbollah-article51-self.php>, accessed August 23, 2006.

MSNBC News On-line (USA), "Israeli Attacks Spawn Environmental Disaster: Bombardment Unleashes Oil into Mediterranean Sea, 
Killing Fish", Turtles, July 26, 2006, <http://www.msnbc.msn.com/ $\mathrm{id} / 14138687 />$, accessed August 19, 2006.

MSNBC News On-line (USA), "Nature Falls Victim to Hezbollah Rocket Attacks", July 26, 2006, <http://www.msnbc.msn.com/ $\mathrm{id} / 14153579 />$, accessed August 19, 2006.

Planet Ark News On-line, "Oil Plant Leak Damages Third of Lebanon's Coast-IMO", July 22, 2006, <http://www.planetark.com/ dailynewsstory.cfm/newsid/37489/newsDate/3-Aug-2006/story. htm>, accessed August 19, 2006.

New America Media, News Digest (USA), "Muslim and Arab Media Question Justification for Israeli Attacks", July 20, 2006, $<$ http://news.newamericamedia.org /news/view_article.html?article

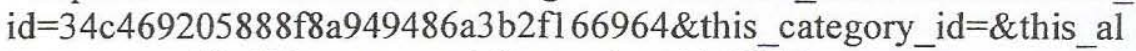
t_category_id=402>, accessed September 11, 2006.

Wikipedia, "Israel-Lebanon Conflict", (2006), <http://en.wikipedia.org/ wiki/2006_Israel-Lebanon_conflict>, accessed September 11, 2006. 